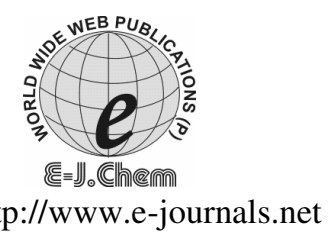

ISSN: 0973-4945; CODEN ECJHAO

E-Journal of Chemistry 2010, 7(2), 457-464

\title{
Scaled Quantum FT-IR and FT-Raman Spectral Analysis of 1-Methoxynaphthalene
}

\author{
M. GOVINDARAJAN ${ }^{*}$, S. PERIANDY ${ }^{\S}$ and K. GANESAN \\ *Department of Physics, Avvaiyar Govt College, Karaikal-609 602, India. \\ ${ }^{\S}$ Department of Physics, Tagore Arts College, Puducherry-605 001, India. \\ Department of Physics, TBML College Porayar-609 307, India. \\ govindarajan64@gmail.com
}

Received 12 September 2009; Accepted 5 November 2009

\begin{abstract}
The structural and vibrational property of 1-methoxynaphthalene has been studied. The fundamental vibrational frequencies and intensity of vibrational bands were evaluated using B3LYP/6-31G $(\mathrm{d}, \mathrm{p})$ basis set and was scaled using various scale factors, which yielded a good agreement between observed and calculated frequencies. The vibrational spectra were interpreted with the aid of normal coordinate analysis. The results of the calculations were applied to simulated spectra of the title compound, which shows excellent agreement with observed spectra. The calculated force constants in vibrational internal coordinates are in closely coincides with the experimentally observed force constants.
\end{abstract}

Keywords: Scaled quantum FT-IR, FT-Raman Spectra, 1-Methoxynaphthalene, Vibrational property.

\section{Introduction}

Vibrational analyses of molecules are more deep study in organic chemistry, for the confirmation of functional groups, molecular structure and reaction kinetics. The naphthalene and its derivatives ${ }^{1,2}$ are the most important class of organic compounds containing two condensed rings. 1-Methoxynaphthalene is used as an intermediate for the synthesis of nonsteroidal anti-inflammatory drugs. It is also used for soap perfumes and in the preparation of non-steroidal anti-inflammatory agents and bromination process. There are series of ladder-like compounds consisting of linearly fused benzene $\operatorname{rings}^{1,2}$, their technological potential ${ }^{3-5}$ and their intrinsic value as models for more complex conjugated molecules have been the subjects of many theoretical and experimental investigations ${ }^{6-14}$. 


\section{Experimental}

The compound under investigation namely 1-methoxynaphthene was purchased from M/S Aldrich chemicals, U.S.A which is of spectroscopic grade and hence used for recording the spectra as such without any further purification. The FT-IR spectrum of the compound was recorded in Bruker IFS $66 \mathrm{~V}$ spectrometer in the range of 4000 to $400 \mathrm{~cm}^{-1}$. The spectral resolution is $\pm 2 \mathrm{~cm}^{-1}$. The FT-Raman spectra of this compound was also recorded in the same instrument with FRA 106 Raman module equipped with Nd: YAG laser source operating at $1.064 \mu \mathrm{m}$ line widths with $200 \mathrm{~mW}$ powers. The spectra were recorded with scanning speed of $30 \mathrm{~cm}^{-1} \mathrm{~min}^{-1}$ of spectral width $2 \mathrm{~cm}^{-1}$. The frequencies of all sharp bands are accurate to $\pm 1 \mathrm{~cm}^{-1}$.

\section{Computational methods}

The quantum chemical calculations were performed for 1-methoxynaphthalene by applying B3LYP/6-31G (d,p) basis set method using the Gaussian $03 \mathrm{~W}$ program ${ }^{15}$. The Cartesian representation of the theoretical force constants has been computed at the fully optimized geometry by assuming $\mathrm{C}_{\mathrm{s}}$ point group symmetry. Scaling of the force field was performed according to the SQM procedure ${ }^{16}$ using selective scaling in the natural internal coordinate representation ${ }^{17}$. The optimized bond lengths and bond angles were used for the calculation of vibrational frequencies at the B3LYP levels. The SCF converges to total energy about500.430925363 and zero point energy $113.19344(\mathrm{kcal} / \mathrm{mol})$. The rotational constants values are $1.64020,0.82882$ and 0.55253 . GAUSSVIEW program $^{18}$ is very helpful for visual interpretation of vibrational frequencies assignments with normal mode of vibration.

\section{Results and Discussion}

\section{Molecular geometry}

The 1-methoxynaphthalene assumed as $\mathrm{C}_{\mathrm{s}}$ point group of symmetry and the optimized geometrical parameters of the title compound are calculated according to labeling of atoms as shown in the Figure 1. The most optimized bond lengths and bond angles of this compound were calculated and shown in Table 1.

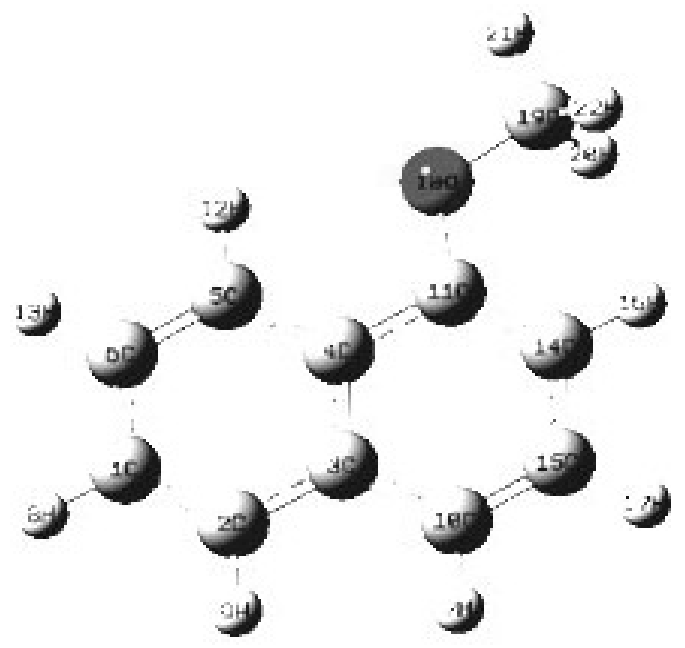

Figure 1. Molecular structure of 1-methoxynaphthalene. 
Table 1. Optimized parameters of 1- methoxynaphthalene.

\begin{tabular}{|c|c|c|c|}
\hline Bond length & Value $\left(\mathrm{A}^{0}\right)$ & Bond angle & Value $\left({ }^{\mathrm{O}}\right)$ \\
\hline $\mathrm{C} 1-\mathrm{C} 2$ & 1.3769 & C2-C1-C6 & 120.2083 \\
\hline C1-C6 & 1.4143 & $\mathrm{C} 1-\mathrm{C} 2-\mathrm{H} 8$ & 120.0527 \\
\hline $\mathrm{C} 1-\mathrm{H} 8$ & 1.0862 & C6-C1-H8 & 119.739 \\
\hline $\mathrm{C} 2-\mathrm{C} 3$ & 1.4203 & $\mathrm{C} 1-\mathrm{C} 2-\mathrm{C} 3$ & 121.0797 \\
\hline C2-H9 & 1.0869 & C1-C2-C9 & 120.405 \\
\hline $\mathrm{C} 3-\mathrm{C} 4$ & 1.4309 & C3-C2-C9 & 118.5153 \\
\hline C3-C10 & 1.4227 & $\mathrm{C} 2-\mathrm{C} 3-\mathrm{C} 4$ & 118.4281 \\
\hline $\mathrm{C} 4-\mathrm{C} 5$ & 1.4184 & C2-C3-C10 & 122.0275 \\
\hline C4-C11 & 1.4336 & $\mathrm{C} 4-\mathrm{C} 3-\mathrm{C} 10$ & 119.5444 \\
\hline C5-C6 & 1.378 & C3-C4-C5 & 119.3869 \\
\hline C5-C12 & 1.0837 & C3-C4-C11 & 118.5468 \\
\hline C6-C13 & 1.0861 & C5-C4-C11 & 122.0663 \\
\hline $\mathrm{H} 7-\mathrm{C} 10$ & 1.0861 & C4-C5-C6 & 120.5573 \\
\hline $\mathrm{C} 10-\mathrm{C} 15$ & 1.3729 & C4-C5-H12 & 118.6985 \\
\hline C11-C14 & 1.3811 & C6-C5-H12 & 120.7442 \\
\hline C11-O18 & 1.3652 & C1-C6-C5 & 120.3396 \\
\hline C14-C15 & 1.417 & C1-C6-H13 & 119.7196 \\
\hline C14-H16 & 1.083 & C5-C6-H13 & 119.9407 \\
\hline C15-H17 & 1.0862 & C3-C10-H7 & 119.0627 \\
\hline O18-C19 & 1.4182 & C3-C10- C15 & 120.1449 \\
\hline C19-H20 & 1.0973 & H7- C10-C15 & 120.7924 \\
\hline C19-H21 & 1.0909 & C4-C11-C14 & 120.6224 \\
\hline \multirow[t]{15}{*}{ C19-H 22} & 1.0973 & C4-C11-O18 & 114.8672 \\
\hline & & C14-C11-O18 & 124.5104 \\
\hline & & $\mathrm{C} 11=\mathrm{C} 14-\mathrm{C} 15$ & 119.925 \\
\hline & & C11-C14-H16 & 120.9587 \\
\hline & & C15-C14-H16 & 119.1163 \\
\hline & & $\mathrm{C} 10-\mathrm{C} 15-\mathrm{C} 14$ & 121.2165 \\
\hline & & C10-C15-H17 & 120.1347 \\
\hline & & C14-C15-H17 & 118.6488 \\
\hline & & C11-O18-C19 & 118.2875 \\
\hline & & O18-C19-H20 & 111.5413 \\
\hline & & O18-C19-H21 & 106.0622 \\
\hline & & O18-C19-H22 & 111.5386 \\
\hline & & $\mathrm{H} 20-\mathrm{C} 19-\mathrm{H} 21$ & 109.2863 \\
\hline & & $\mathrm{H} 20-\mathrm{C} 19-\mathrm{H} 22$ & 109.0488 \\
\hline & & $\mathrm{H} 21-\mathrm{C} 19-\mathrm{H} 22$ & 109.2914 \\
\hline
\end{tabular}

Vibrational analysis and theoretical prediction of spectra

The sixty normal modes of vibrations of 1-methoxynaphthalene are distributed by symmetry species as

$$
\Gamma \text { vib }=41 \mathrm{~A}^{\prime} \text { (in-plane) }+19 \mathrm{~A}^{\prime \prime} \text { (out-of-plane) }
$$

It is in agreement with $\mathrm{C}_{\mathrm{s}}$ point group symmetry, all vibrations are active both in FTRaman and infrared absorption. The detailed vibrational assignments of fundamental modes of 1-methoxynaphthalene along with the calculated frequencies, IR intensities, Raman activities and polarization ratios are reported in the Table 2 . The observed and simulated FTIR and laser Raman spectra are presented in Figures $2 \& 3$ respectively. 
Table 2. Observed and B3LYP 6-31G (d,p) level calculated vibrational frequencies of 1-methoxynaphthalene.

\begin{tabular}{|c|c|c|c|c|c|c|c|c|c|c|c|}
\hline$\underset{\sim}{\stackrel{\overbrace{}}{E}}$ & $\mathscr{E}$ & 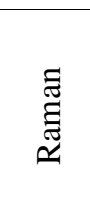 & 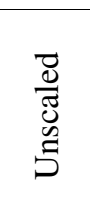 & $\frac{\vec{d}}{\frac{d}{\tilde{D}}}$ & 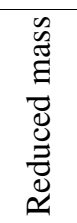 & 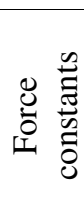 & 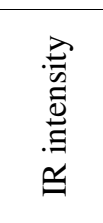 & 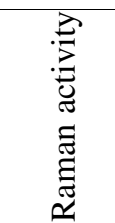 & 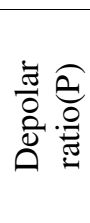 & 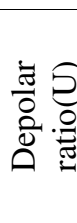 & 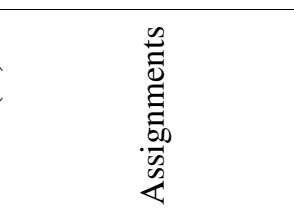 \\
\hline$A^{\prime}$ & 3065 & & 3227 & 3065 & 1.09 & 6.69 & 7.59 & 201.60 & 00.11 & 0.20 & C-H stretch \\
\hline $\mathrm{A}^{\prime}$ & & 3060 & 3226 & 3064 & 1.09 & 6.69 & 12.39 & 46.33 & 0.58 & 0.73 & C-H stretch \\
\hline $\mathrm{A}^{\prime}$ & & 3055 & 3201 & 3040 & 1.09 & 6.61 & 28.85 & 268.79 & 0.14 & 0.24 & C-H stretch \\
\hline$A^{\prime}$ & & 3050 & 3198 & 3037 & 1.09 & 6.59 & 31.92 & 212.82 & 0.39 & 0.56 & C-H stretch \\
\hline $\mathrm{A}^{\prime}$ & & 3020 & 3187 & 3027 & 1.09 & 6.52 & 15.12 & 127.75 & 0.74 & 0.85 & C-H stretch \\
\hline$A^{\prime}$ & & 3010 & 3180 & 3021 & 1.08 & 6.47 & 1.76 & 48.82 & 0.74 & 0.85 & C-H stretch \\
\hline $\mathrm{A}^{\prime}$ & 3005 & & 3175 & 3015 & 1.08 & 6.44 & 1.14 & 42.82 & 0.63 & 0.78 & C-H stretch \\
\hline$A^{\prime}$ & & 2990 & 3150 & 2992 & 1.10 & 6.43 & 22.29 & 106.12 & 0.52 & 0.68 & C-H stretch \\
\hline $\mathrm{A}^{\prime}$ & 2940 & & 3080 & 2925 & 1.10 & 6.18 & 40.46 & 62.39 & 0.75 & 0.85 & C-H stretch \\
\hline $\mathrm{A}^{\prime}$ & 2860 & & 3017 & 2865 & 1.03 & 5.54 & 60.81 & 136.48 & 0.03 & 0.06 & C-H str \\
\hline$A^{\prime}$ & & 1640 & 1682 & 1631 & 6.29 & 10.49 & 7.1218 & 6.98 & 0.54 & 0.70 & C-O str \\
\hline$A^{\prime}$ & 1595 & & 1653 & 1586 & 5.09 & 8.20 & 19.53 & 1.93 & 0.28 & 0.44 & C-C stretch \\
\hline$A^{\prime}$ & & 1580 & 1633 & 1567 & 6.75 & 10.60 & 64.91 & 57.52 & 0.60 & 0.75 & C-C stretch \\
\hline $\mathrm{A}^{\prime}$ & & 1505 & 1562 & 1499 & 3.54 & 5.08 & 21.39 & 7.82 & 0.29 & 0.46 & C-C stretch \\
\hline$A^{\prime}$ & 1465 & & 1520 & 1461 & 1.09 & 1.49 & 13.74 & 8.50 & 0.59 & 0.74 & $\mathrm{C}-\mathrm{H}$ in plane bend \\
\hline$A^{\prime}$ & 1460 & & 1509 & 1451 & 2.03 & 2.73 & 32.80 & 14.17 & 0.49 & 0.66 & $\mathrm{C}-\mathrm{H}$ in plane bend \\
\hline$A^{\prime}$ & 1459 & & 1503 & 1442 & 1.04 & 1.39 & 5.49 & 24.98 & 0.75 & 0.85 & C-C str \\
\hline$A^{\prime}$ & 1440 & & 1489 & 1431 & 1.50 & 1.96 & 3.23 & 9,00 & 0.28 & 0.43 & $\mathrm{C}-\mathrm{H}$ in plan \\
\hline$A^{\prime}$ & & 1435 & 1483 & 1426 & 1.81 & 2.34 & 19.20 & 45.48 & 0.37 & 0.54 & $\mathrm{C}-\mathrm{H}$ in plane bend \\
\hline$A^{\prime}$ & & 1385 & 1438 & 1380 & 2.21 & 2.69 & 97.08 & 19.94 & 0.19 & 0.33 & C-C stretch \\
\hline$A^{\prime}$ & 1325 & & 1418 & 1325 & 5.65 & 6.70 & 0.99 & 178.62 & 0.18 & 0.31 & C-O stretch \\
\hline$A^{\prime}$ & 1310 & & 1391 & 1334 & 3.54 & 4.04 & 1.27 & 4.46 & 0.34 & 0.51 & C-C stretch \\
\hline$A^{\prime}$ & & 1260 & 1305 & 1255 & 2.56 & 2.57 & 149.46 & 2.00 & 0.67 & 0.80 & $\mathrm{C}-\mathrm{H}$ in plane bend \\
\hline$A^{\prime}$ & 1220 & & 1274 & 1225 & 1.73 & 1.66 & 51.44 & 2.65 & 0.60 & 0.75 & $\mathrm{C}-\mathrm{C}$ in pla \\
\hline$A^{\prime}$ & 1190 & & 1247 & 1199 & 2.08 & 1.90 & 3.05 & 1.81 & 0.54 & 0.70 & $\mathrm{C}-\mathrm{H}$ in plane bend \\
\hline$A^{\prime}$ & 1175 & & 1223 & 1176 & 1.41 & 1.24 & 4.39 & 5.11 & 0.64 & 0.78 & $\mathrm{C}-\mathrm{H}$ in plane bend \\
\hline$A^{\prime}$ & 1160 & & 1203 & 1156 & 1.42 & 1.21 & 6.75 & 4.90 & 0.72 & 0.84 & $\mathrm{C}-\mathrm{H}$ in plane bend \\
\hline$A^{\prime}$ & & 1155 & 1185 & 1139 & 1.14 & 0.95 & 8.96 & 3.12 & 0.70 & 0.82 & $\mathrm{C}-\mathrm{H}$ out plane bend \\
\hline$A^{\prime}$ & & 1140 & 1178 & 1132 & 1.27 & 1.04 & 0.85 & 4.56 & 0.75 & 0.85 & $\mathrm{C}-\mathrm{H}$ in plane bend \\
\hline$A^{\prime}$ & 1105 & & 1175 & 1129 & 1.33 & 1.08 & 2.61 & 9.79 & 0.68 & 0.81 & $\mathrm{C}-\mathrm{H}$ in plane bend \\
\hline$A^{\prime}$ & 1075 & & 1138 & 1092 & 2.66 & 2.03 & 74.68 & 2.95 & 0.20 & 0.33 & C-C stretch \\
\hline$A^{\prime}$ & 1025 & & 1101 & 1042 & 2.19 & 1.56 & 15.22 & 5.63 & 0.13 & 0.24 & C-C stretch \\
\hline$A^{\prime}$ & 995 & & 1052 & 1011 & 2.37 & 1.54 & 11.00 & 12.63 & 0.15 & 0.27 & $\mathrm{C}-\mathrm{H}$ in plane bend \\
\hline$A^{\prime}$ & & 990 & 1019 & 978 & 6.07 & 3.72 & 5.85 & 1.44 & 0.74 & 0.85 & $\mathrm{C}-\mathrm{H}$ out plane bend \\
\hline$A^{\prime}$ & 974 & & 994 & 977 & 1.26 & 0.73 & 0.00 & 0.12 & 0.75 & 0.85 & $\mathrm{C}-\mathrm{C}-\mathrm{C}$ in plane bend \\
\hline$A^{\prime}$ & 971 & & 969 & 952 & 1.30 & 0.72 & 1.70 & 0.10 & 0.75 & 0.85 & $\mathrm{C}-\mathrm{C}-\mathrm{C}$ in plane bend \\
\hline$A^{\prime}$, & & 960 & 960 & 921 & 1.29 & 0.70 & 0.09 & 0.39 & 0.75 & 0.85 & $\mathrm{C}-\mathrm{H}$ out plane bend \\
\hline$A^{\prime}$ & & 875 & 888 & 872 & 1.57 & 0.73 & 0.71 & 4.91 & 0.75 & 0.85 & $\mathrm{C}-\mathrm{C}-\mathrm{C}$ in plane bend \\
\hline$A^{\prime}$, & 863 & & 874 & 839 & 4.63 & 2.08 & 2.00 & 4.78 & 0.11 & 0.20 & $\mathrm{C}-\mathrm{H}$ out plane bend \\
\hline
\end{tabular}




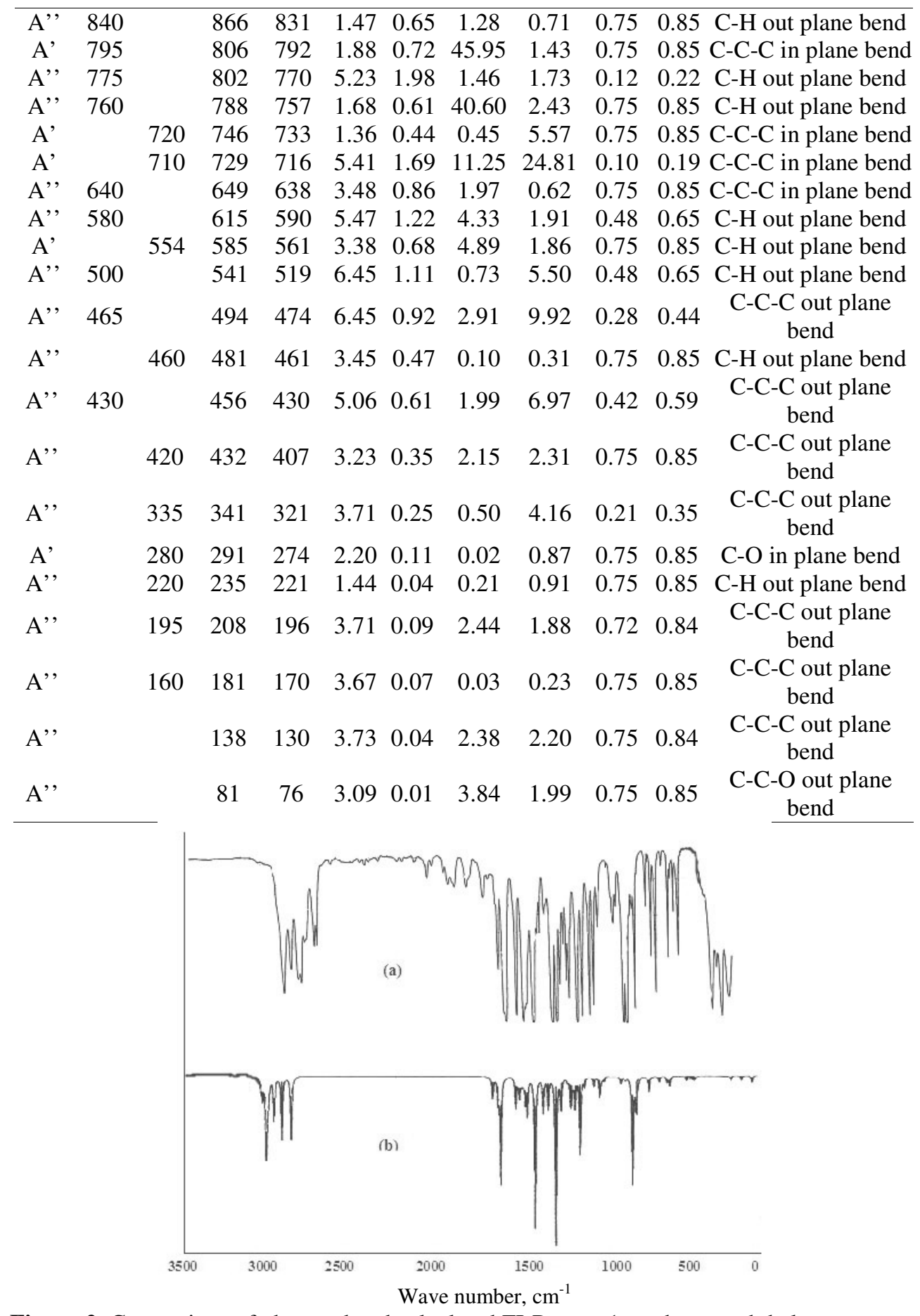

Figure 2. Comparison of observed and calculated FI-Raman 1-methoxynaphthalene.

(a) Observed (b) calculated with B3LYP/6-31G (d,p). 


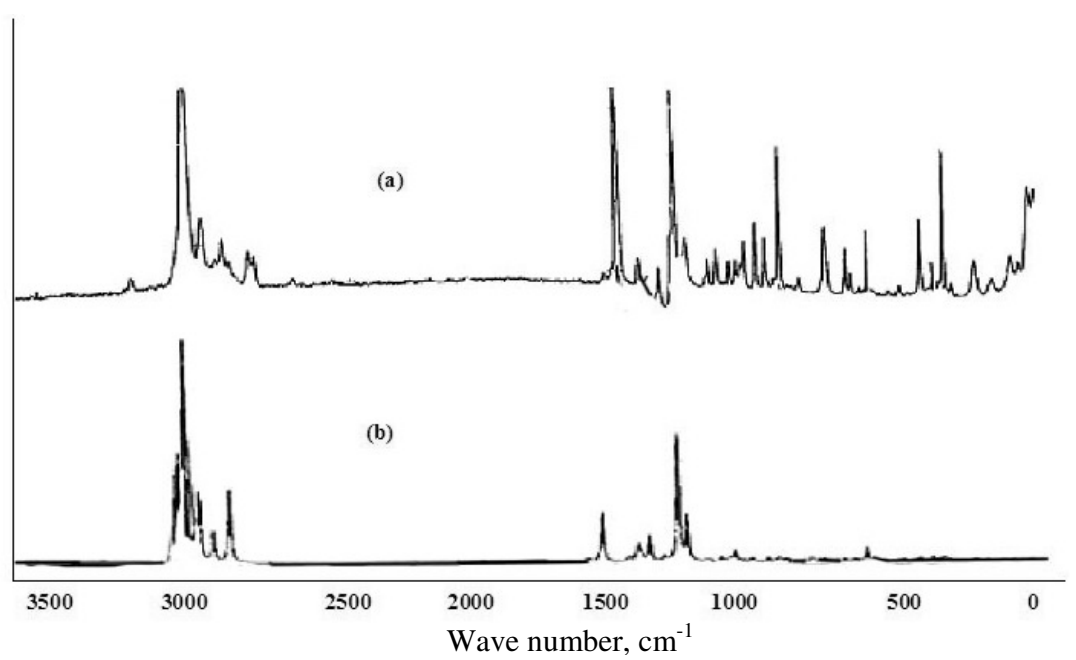

Figure 3. Comparison of observed and calculated FT-Raman 1-methoxynaphthalene (a) Observed (b) calculated with B3LYP/6-31G (d,p).

Root mean square (RMS) values of frequencies were obtained using the relation

$$
v_{\mathrm{RMS}}=\sqrt{\frac{1}{n-1} \sum_{i}^{n}\left(v_{i}{ }^{\text {calcu }}-v_{i}{ }^{\exp }\right)^{2}}
$$

The RMS error of unscaled frequencies is obtained for 1-methoxy naphthalene and found to be $77.04 \mathrm{~cm}^{-1}$. In order to reproduce the observed frequencies, the refinement through scaling factors was carried out and optimized RMS deviation was reduced to $12.1 \mathrm{~cm}^{-1}$.

\section{C- $H$ Vibrations}

In aromatic molecules like 2 naphthalenol C-H vibrations appear ${ }^{19}$ in the region $3085-3040 \mathrm{~cm}^{-1}$ and in 2,4 diisopropylnaphthalene $\mathrm{e}^{20}$ in the region $3070-3030 \mathrm{~cm}^{-1}$. In this compound the $\mathrm{C}-\mathrm{H}$ stretch vibrations occur in the region $3065-3000 \mathrm{~cm}^{-1}$. The upper limit of frequency comparatively decreases may be due to the presence of oxygen and methyl group. There are seven aromatic C-H stretching vibrations, are observed at 3060, 3055, 3050, 3020 and $3010 \mathrm{~cm}^{-1}$ in FT-Raman and 3065 and $3005 \mathrm{~cm}^{-1}$ are in IR region. The maximum and minimum frequencies are lies in the IR region. The mean deviations between experimental and scaled calculated frequencies are nearly $8.57 \mathrm{~cm}^{-1}$. The scaled vibrations are good in agreement with the experimentally reported values of naphthalene derivatives. Optimized $\mathrm{C}-\mathrm{H}$ bond lengths are clearly shows that the $\mathrm{C}-\mathrm{H}$ bonds nearer to the methoxy group $\mathrm{C}_{5}-\mathrm{H}_{12}$ and $\mathrm{C}_{15}-\mathrm{H}_{16}$ having maximum variation with others. This is undoubtedly due to the impact of methoxy group. It is also evident by the farthest bond $\mathrm{C}_{2}-\mathrm{H}_{13}$ with maximum optimized bond length.

\section{Methyl group vibrations}

The methyl group stretching vibrations are in the region $3000-2980 \mathrm{~cm}^{-1}$. In this compound, there two asymmetric and one symmetric C-H stretching vibrations are appeared at 2990, 2940 and $2860 \mathrm{~cm}^{-1}$ respectively. These assignments are also evidenced by literature values $^{21}$. The calculated frequencies are at 2992,2940 and $2865 \mathrm{~cm}^{-1}$. Usually the symmetrical bands are sharper than the asymmetrical bands. The same trend is appeared here also. 
2-methoxy-1-naphthaldhyde shows methyl vibrations are in the range $2885-2803 \mathrm{~cm}^{-1}$. This may be indicates that the additional substitutions are pushes down the range of vibration. The asymmetric and symmetric stretching modes of methyl group attached the benzene ring are usually downshifted due to electronic effects and are expected near 2925 and $2865 \mathrm{~cm}^{-1}$ asymmetric and symmetric stretching vibration. This evident that the same electronic effect is also applicable in double ring compound like 1-methoxynaphthalene and the vibrations are observed ${ }^{22}$ at 2940 and $2865 \mathrm{~cm}^{-1}$. Here also the above experimental values coincide with the scaled B3LYP/6-31G (d, p) basis set values. There is an appreciable change in one calculated $\mathrm{C}_{19}-\mathrm{H}_{21}$ bond due to its orientation and very near to the oxygen atom.

The bands due to $\mathrm{C}-\mathrm{H}$ in-plane bending vibration interact some what with $\mathrm{C}-\mathrm{C}$ stretching vibrations, are observed as number of bands in the region $1300-1000 \mathrm{~cm}^{-1}$. The C-H out-of-plane bending vibrations occur ${ }^{23}$ in the region $900-667 \mathrm{~cm}^{-1}$.

In the present investigation, the bands observed at 1465, 1460, 1440, 1435, 1260, 1220, 1190, $1175,1160,1155,1140,1105$ and $1075 \mathrm{~cm}^{-1}$ and $1025 \mathrm{~cm}^{-1}$ are assigned to $\mathrm{C}-\mathrm{H}$ in plane bending vibration. The $\mathrm{C}-\mathrm{H}$ out of plane bending modes was also assigned at 995, 974, 971, 875, 863, 795, $775,720,640,290$ and $220 \mathrm{~cm}^{-1}$ within characteristic region except three and is presented.

\section{C-O vibrations}

The compounds contain a carbonyl group; the absorption caused by the $\mathrm{C}-\mathrm{O}$ stretching is generally very strong ${ }^{24}$. In $p$-anisaldehyde, the C-O vibration with B3LYP/6-31G(d,p) predicated frequencies at 1332 and $1305 \mathrm{~cm}^{-1}$ are agreement with experimental frequencies ${ }^{25}$ at 1322 and $1291 \mathrm{~cm}^{-1}$. The characteristic infrared absorption frequencies of carbonyl group in cyclic ketones are normally strong in intensity and found in the region $1685-1660 \mathrm{~cm}^{-1}$. Carboxylic acids, the $\mathrm{C}=\mathrm{O}$ stretching observation ${ }^{26}$ observed at $1725 \pm 65$. In this compound $\mathrm{C}=\mathrm{O}$ and $\mathrm{C}-\mathrm{O}$ stretching vibrations are observed at 1640 and $1325 \mathrm{~cm}^{-1}$. The bands are strong and medium appeared in Raman and IR. The scaled calculated values obtained from B3LYP/6-31G (d,p )l are 1631 and $1325 \mathrm{~cm}^{-1}$. The in plane bending vibration is observed at $280 \mathrm{~cm}^{-1}$.

\section{C-C vibrations}

Generally the $\mathrm{C}-\mathrm{C}$ stretching vibrations in aromatic compounds form ${ }^{27}$ the band in the region of 1430 to $1650 \mathrm{~cm}^{-1}$. In the present case investigation the bands are observed at $1640,1595,1580,1505,1440,1325$ and $1310 \mathrm{~cm}^{-1}$. The last two bands lie below the expected range, this may be due to the substitution of heavy elements oxygen and methyl group in the present case. The in-plane bending $\mathrm{C}-\mathrm{C}$ vibrations generally occur at higher frequencies than of out-of-plane bending ${ }^{28}$. In the present study the bands observed at 760, 720, 580, 500, 465 and 430 are assigned to $\mathrm{C}-\mathrm{C}$ in plane bending modes. The out of plane bending modes of frequencies are attributed to 554, 460 and $420 \mathrm{~cm}^{-1}$ in Raman and 175, 140 and $85 \mathrm{~cm}^{-1}$ in IR.

\section{Conclusions}

A complete vibrational analysis of 1-methoxynaphthalene was performed on the basis of DFT functional calculations at B3LYP/6-31G (d, p) basis level. The influences of carbonoxygen, and methyl group in the vibrational frequencies of the title compound were discussed. The observed and stimulated spectra are in agreement and show a good frequency fit. The difference between theoretical and experimental wave numbers within $10 \mathrm{~cm}^{-1}$ shows that the assignments of the fundamentals are valid, by the qualitative agreement between the calculated and observed frequencies.

\section{References}

1. Clar E, Polycyclic Hydrocarbons, Academic Press, London, 1964. 
2. Havey R G, Polycyclic Aromatic Hydrocarbons, Wiley-VCH, New York, 1997.

3. Geerts Y, Klarner G and Mullen K, in Electronic Materials: The Oligomer Approach, Edited by Mullen K and Wagner G, Wiley-VCH, Weinheim, 1998, p. 48.

4. Dimitrakopoulos C D and Malenfant P R L, Adv Mater., 2002, 14, 99.

5. Reese C, Roberts M, Ling M and Bao Z, Mater Today, 2004, 7, 20

6. Bendikov M, Wudl F and Perepichka D F, Chem Rev., 2004, 104, 4891

7. Angliker H, Rommel E and Wirz J, Chem Phys Lett., 1982, 87, 208.

8. Kertesz M and Hoffmann R, Solid State Comm., 1983, 47, 97.

9. Kivelson S and Chapman O L, Phys Rev B., 1983, 28, 7236.

10. Wiberg K B, J Org Chem., 1997, 62, 5720.

11. Houk K N, Lee P S and Nendel M, J Org Chem., 2001 66, 5517-5521.

12. Bendikov M, Duong H M, Starkey K, Houk K N, Carter E A and Wudl F, J Am Chem Soc., 2004, 126, 7416.

13. Mondal R, Shah B K and Neckers D C, J Am Chem Soc., 2006 ,128, 9612.

14. Reddy A R and Bendikov M, Chem Commun., 2006, 1179.

15. Frisch M J, Trucks G W, Schlegel H B, Scuseria G E, Robb M A, Cheeseman J R, Montgomery J A, Jr, Vreven T, Kudin K N, Burant J C, Millam J M, Iyengar S S, Tomasi J, Barone V, Mennucci B, Cossi M, Scalmani G, Rega N, Petersson G A, Nakatsuji H, Hada M, Ehara M, Toyota K, Fukuda R, Hasegawa J, Ishida M, Nakajima T, Honda Y, Kitao O, Nakai H, Klene M, Li X, Knox J E, Hratchian H P, Cross J B, Adamo C, Jaramillo J, Gomperts R, Stratmann R E, Yazyev O, Austin A J, Cammi R, Pomelli C, Ochterski J W, Ayala P Y, Morokuma K, Voth G A, Salvador P, Dannenberg J J, Zakrzewski V G, Dapprich S, Daniels A D, Strain M C, Farkas O, Malick D K, Rabuck A D, Raghavachari K, Foresman J B, Ortiz J V, Cui Q, Baboul A G, Clifford S, Cioslowski J, Stefanov B B, Liu G, Liashenko A, Piskorz P, Komaromi I, Martin R L, Fox D J, Keith T, Al-Laham M A, Peng C Y, Nanayakkara A, Challacombe M, Gill P M W, Johnson B, Chen W, Wong M W, Gonzalez C and Pople J A, Gaussian Inc., Wallingford, CT, 2004.

16. Pulay P, Fogarasi G, Pongor G, Boggs J E and Vargha A, J Am Chem Soc., 1983, 105, 7037.

17. Fogarasi G, Zhov X, Taylor P W and Pulay P, J Am Chem Soc., 1992, 114, 8191.

18. Fogarasi G and Pulay P in: Durig J R (Ed.), Vibrational Spectra and Structure, Elesevier, Amsterdam, 1985, 14, 125.

19. Chis V, Oltean M, Pirnau A, Miclaus V and Filip S, J Optoelectron Adv Mater., 2006, 8(3), 1143.

20. Michal. H Jamroz, Jan Cz Dobrowolski and Robert Brzozowski, J Mol Struct., 2006, 787, 172-183.

21. Bunce S J, Edwards H G, Johnson A F, Lewis I R and Turner P H, Spectrochim Acta., 1993, 49A, 775.

22. Jag Mohan, Organic Spectroscopy-Principles and applications, second Ed., Narosa publishing House, New Delhi, 2001.

23. Bowman W D and Spiro T G, J Chem Phys., 1980, 73, 5482.

24. Chalasinski M and Szczesnaik M, Chem Rev., 1994, 94, 1723.

25. Gunsekaran S, Seshadri S, Muthu S, Kumaresan S and.Arunbalaaji R, Spectrochim Acta A, Mol Biomol Spectrosc., 2008, 70(3), 550-556.

26. Asha Raj, Raju K, Hema Tresa Varghese, Carlos M, Granadeiro, Helena I S, Nogueira and C, Yohannan Panicker, J Braz chem Soc., 2009, 20(3),549-559

27. Varasanyi G, Vibrational Spectra of Benzene Derivatives, Academic Press, New York, 1969.

29. Socrates G, Infrared and Raman Characteristic Group Frequencies, $3^{\text {rd }}$ Ed., John Wiley \& Sons, Ltd., Chichester, 2001. 


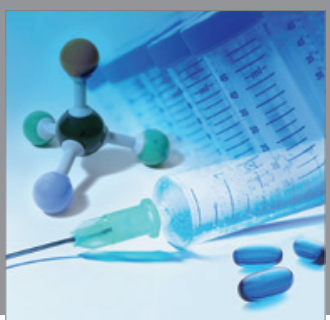

International Journal of

Medicinal Chemistry

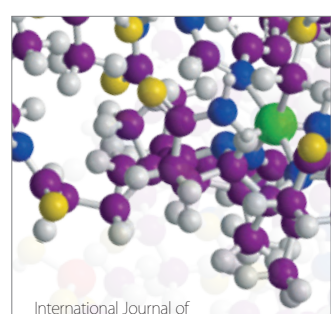

Carbohydrate Chemistry

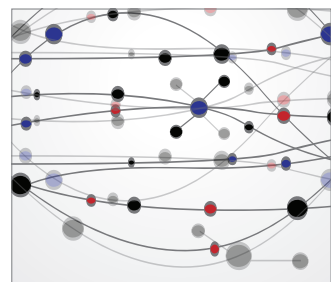

The Scientific World Journal
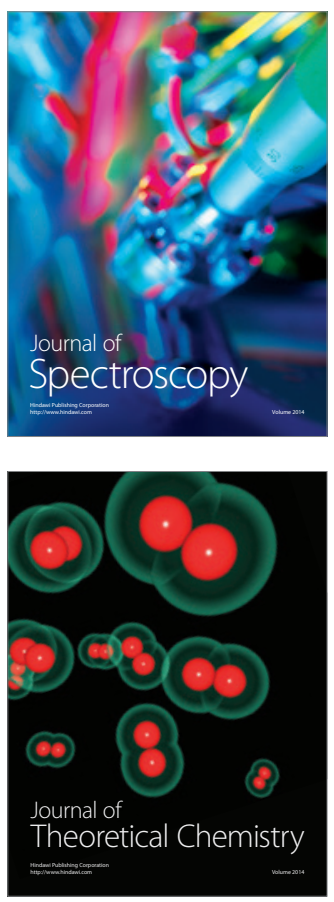
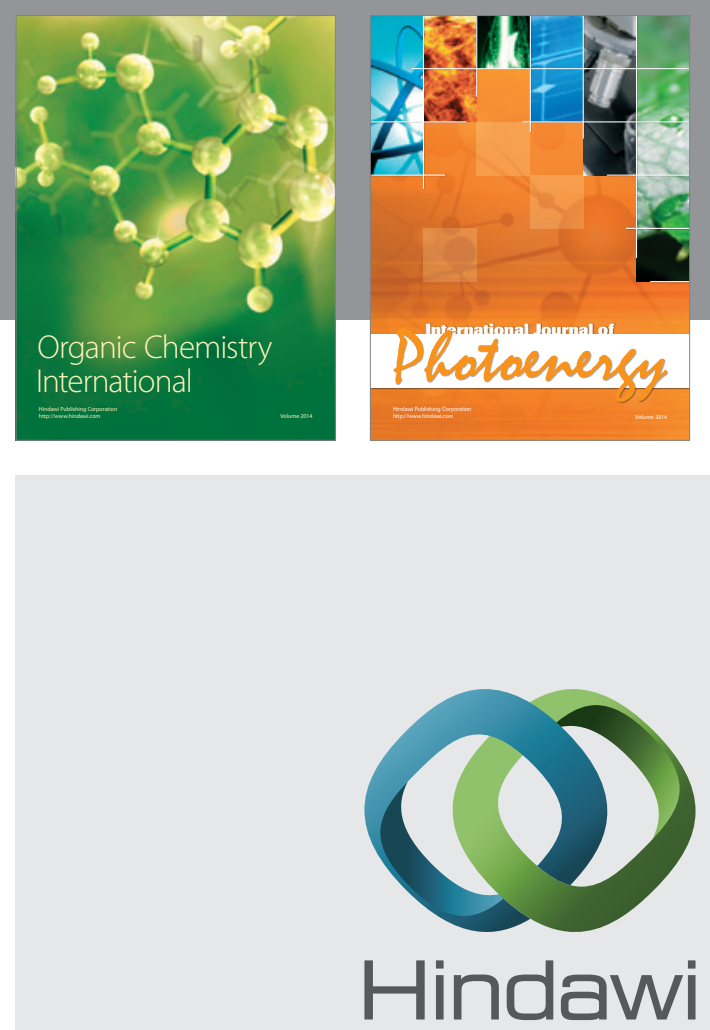

Submit your manuscripts at

http://www.hindawi.com
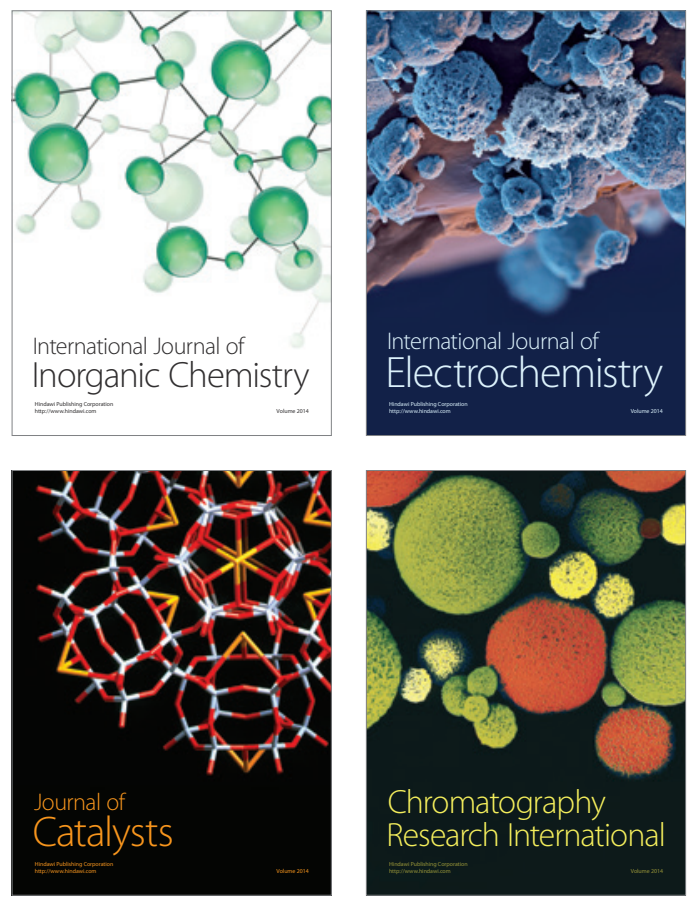
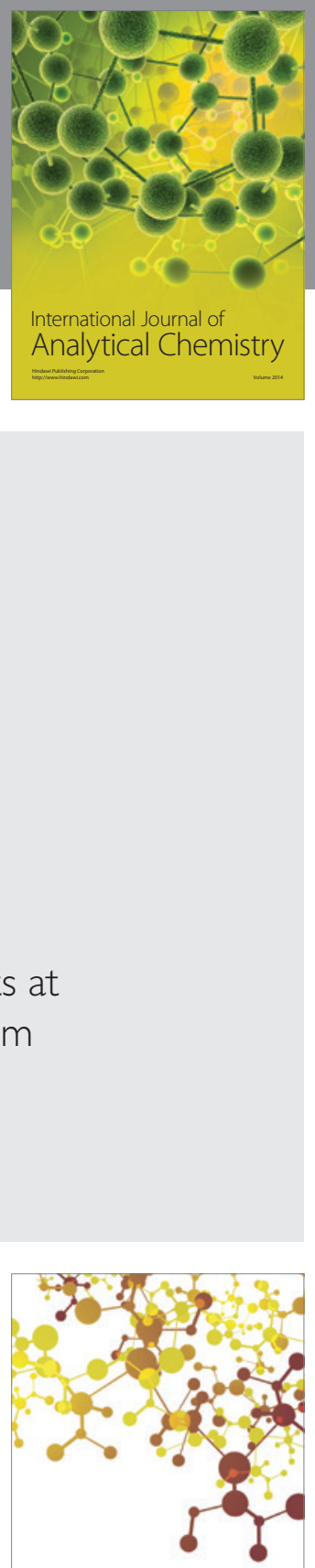

Journal of

Applied Chemistry
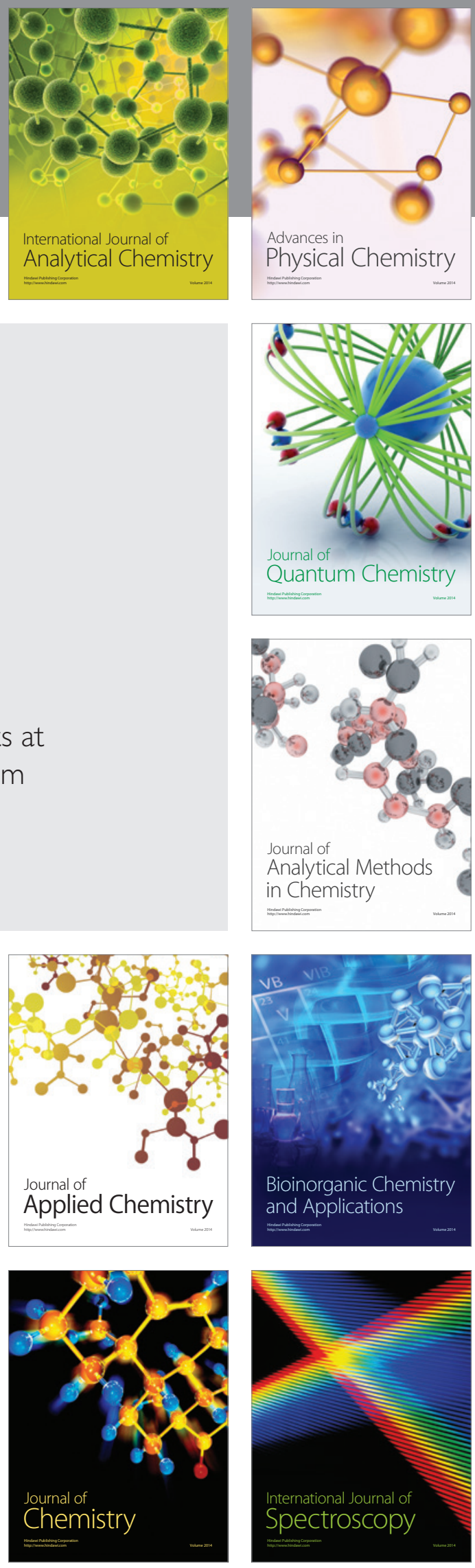